\title{
Az északkeleti nyelvjárási régió kései középmagyar kori hangállapotáról Barkóczy Krisztina levelei alapján
}

1. Bevezetés. Barkóczy Krisztina (1670-1724) 1687-ben lett gróf Károlyi Sándornak (1669-1743), Szatmár vármegye főispánjának, a Rákóczi-szabadságharc későbbi vezérének a felesége. Mivel életük jelentős része háborús időkre esett, s emiatt Károlyi az ország különböző pontjain hadakozott, éveken át föleg levelekben tartották a kapcsolatot egymással. KOVÁCS ÁGNES és FOGARASSY ZOLTÁN 2011-ben adta ki a Barkóczy Krisztina levelei férjéhez, Károlyi Sándorhoz címü kötetet, amely több mint egy évtized levelezését öleli fel 1698-tól 1711ig. A 328 levélből kirajzolódik a Rákóczi-szabadságharc küzdelmeinek hátterében zajló mindennapi élet is. Barkóczy Krisztina anyai és háziasszonyi teendői mellett férje távollétében férfiként állt helyt a gazdaságban, s az előtte álló feladatokról szorgalmasan beszámolt Károlyinak, kikérve tanácsát vagy beleegyezését.

Barkóczy Krisztina a család salánki (Ugocsa vm.) és gelénesi (Bereg vm.) birtokán nevelkedett, majd férjével a Károlyi család Szatmár vármegyei birtokaira, előbb Olcsvára, később Károlyba költöztek. Az 1698-1711 közötti zaklatott években Krisztina gyermekeivel együtt a fentieken kívül hosszabb-rövidebb ideig tartózkodott Csengerben (Szatmár vm.), Munkácson (Bereg vm.), Nagyszőlősön (Ugocsa vm.), (Nyír)Baktán, Kisvárdán és Szentmártonban (Szabolcs vm.). Mint az említett helynevek is elárulják, a levelek írója születési helye és családi birtokaik révén elsősorban az északkeleti nyelvjárási régióhoz (vö. JUHÁsz 2001: 292) kötődött, de Kassán, Radványban (Abaúj vm.), illetve a zempléni Újhelyben, Hernádnémetiben és (Tisza)Tardoson, sőt Egerben is megfordult.

Barkóczy Krisztina iskoláiról nincsenek adataink, de leveleiböl kiderül, hogy müvelt, olvasott asszony volt, hiszen rendszeresen rendelt magyar nyelvü könyveket, így az olvasásnak köszönhetően tisztában lehetett korának irodalmi nyelvével. Írásaiból azonban elénk tárulnak a régió nyelvjárási jellemzői is, akár a szavak hangalakjában, akár az alaktani elemekben vagy a szókincsben és a szólásokban. Szövegei igen közel állnak a beszélt nyelvi stílushoz, hiszen saját, tágabb környezetéből, az északkeleti régióból nem mozdult ki, nem követte hivatali teendőit intéző urát Pozsonyba vagy Bécsbe. Így érthető, hogy leveleiben idegen hatás nem érezhető, mondanivalóját gazdag és választékos szókinccsel fejezi ki, helyi ízekkel, fordulatokkal és szólásokkal füszerezi. A következőkben e levelek hangalaki jellemzőit vizsgáljuk meg.

Mivel a könnyebb olvashatóság érdekében a kötet összeállítói a mai helyesíráshoz igazították többek között az ékezethasználatot vagy a hasonulások és a mássalhangzó-összeolvadások írásmódját (vö. FoGARASSY-KovÁCS 2011: 9), ezért a magánhangzók időtartamát és a mássalhangzók egymásra hatását (egy-két jelölt kivételtől eltekintve) nem vettük be a vizsgálat körébe. 


\section{Barkóczy Krisztina nyelvhasználatának hangtani jellemzői férjéhez írott levelei alapján}

\subsection{A magánhangzók jellemzői}

2.1.1. Zárt-nyílt megfelelések. A magánhangzók zárt-nyílt viszonylatában a legszembetünőbb a zárt $i$-zés, amelynek az északkeleti nyelvjárási régió az egyik gócpontja lehetett, hiszen mint ABAFFY is megállapítja: a „16. század legerősebben $i$-ző szerzője a Szatmár megyei Szinyérváralján született Erdősi Sylvester János, aki az egész Újtestamentumot $i$-ző nyelvjárásban fordította le, és adta ki.[...]. A két Telegdynek Bihar-Szabolcs-Szatmárra lokalizálható nyelve ugyanilyen erösen í-ző" (ABAFFY 2003: 606). Az Ugocsában, Beregben, Szatmárban otthonos Barkóczy Krisztinánál - levelei tanúsága szerint - még a 17-18. század fordulóján is gyakori az $i$-zés szótőben, hangsúlyos szótagban: ipitésbe $(1708 / 213)^{1}$, kinyes (1710/323), kísem (1710/361), kiszitem (1711/406), pintek (1708/268), pínz (1698/13); valamint hangsúlytalan szótagban: dicsíri (1710/364), edínyekbe (1708/253), erszinye (1708/267), igírkezet (1705/64), leginyek (1705/72), seríny (1704/39), szegíny (1705/ 67); de ingadozást is tapasztalhatunk: kínesö 'higany' $(1706 / 131) \sim$ kéneső $(1711 / 402)$. Az $i$-zés a tulajdonnevekben - hely- és személynevekben - is megjelenik: Berinybe (1710/336), pater Berínyit (1706/149), Jászberínybe (1710/368), de közöttük gyakori az ingadozás, akár ugyanabban a levélben is: Naminyival Naményit (1708/229).

Az $i$-zés alaktani elemeket is érint: az -é birtokjelben és a -ként határozóragban fordult elö az $i$ : magamít (1710/359), ,egyenkint-kettenkint jü" (1708/218), máskint (1705/63).

A Barkóczy család egykori lakóhelyének, a ma nyelvjárásszigetként emlegetett Salánknak a nyelvjárásáról szólva a környéktől különböző zárt ë-zése mellett a zárt $i$-zést emeli ki LiZANYEC PÉTER és HORVÁTH KATALIN (1982: 3), Olcsva 15. századi $i$-zésére pedig N. FODOR JÁNOS is utal (2008: 148).

A zártabb magánhangzók kedvelése megmutatkozik az $a \sim o$ viszonylatában is. Az o-zás szótőben hangsúlyos szótagban: fokadoz (1705/64), jovára (1698/20), Máramoros (1704/39), motring (1706/127), szovát (1710/364); valamint hangsúlytalan helyzetben: boszonkodjék (1698/20), nyavolyám (1710/377), relatív tövekben a - $t$ tárgyrag és a birtokos személyjel, illetve többesszám jele között, továbbá az -an modalis-essivus ragban jelentkezik: citromokot (1705/63), Hajdúkot (1710/363), jókot (1698/14), Klárikámot (1698/13), magamot (1698/20), rabokot (1704/40), szattyánokot (1710/363), újobban (1698/17), szorosson (1705/89). Ezt a jelenséget ABAFFY a középmagyar korban erdélyi, különösen székelyföldi jelenségnek tartja (2003: 604), példáink azonban az északkeleti nyelvjárási régióban való elterjedtségéröl is tanúskodnak, sőt HoRVÁTH KATALIN kutatásai szerint (1982: 5-6) tovább él a mai kárpátaljai nyelvhasználatban is.

A zártabb magánhangzó használata az o/ó $\sim u$ ú és az $o ̈ \sim \ddot{u}$ esetében az előbbieknél kisebb mértékben jelentkezik, hangsúlyos szótagban gyakrabban, de hangsúlytalan szótagban is előfordul: csudálom (1705/62), burítva (1706/127), rullok (1710/302), finum (1704/40), távul (1710/358), lúra (1703/33), hernyú

${ }^{1}$ A levelek lelöhelyére a levél keletkezésének évszámával és a fent említett kötetbeli lapszámával utalok. 
(1706/135), báránybüröket (1710/364), bü (1705/65), büdöskü (1711/406), füfájással (1706/121), fükötöt (1710/302), jü (1698/13) jünek (1698/21), küvári (1708/232), Szarvaskübe (1710/345), szühetne (1708/207), ütet (1704/45), tüllök (1710/366), Hetfün (1698/22), de a jön ige tövében néha megjelenik az ö is: jöne (1698/14). Az $o \dot{o} \sim \dot{u}$ és $\mathscr{o} \sim u ̋$ kettőssége ABAFFY (2003: 607) szerint „,nem terheli meg olyan erőteljesen e fonémák gyakoriságát, mint az $i$-zés vagy é-zés, de olyannyira jellemzi a nyelvjárásokat, hogy a legkorábbi nyelvtanoktól kezdve szó esik róluk"; sőt azt is lehetségesnek tartja, hogy az $\dot{u}, \ddot{u}$ változat az $i$-ző nyelvjárással jár együtt, és egyéb példák mellett megemlíti az északkeleti, valamint az erdélyi nyelvjárást. E hangtani jelenség hatóköre Barkóczy Krisztina leveleinek tanúsága szerint a 17-18. században is érintette az északkeleti nyelvjárási régiót.

Az előzőkkel ellentétes tendencia, a zártabb magánhangzóval szemben a nyíltabb vokális szintén megtalálható néhány szóban, például a nyílt é-zés, $i / i$ é: épétése (1705/71), kéméltem (1706/128), késérő (1710/363), kerétek 'kerítek' (1710/338), mindég (1710/375), szerént (1698/13); akárcsak a nyílt e-zés: esmerni (1706/147), heuzmál 'hiúzmál' (1706/115).

Az $u \sim o$ viszonylatában csak néhány idegen szóban fordult elö a nyíltabb magánhangzó: jesoviták (1706/137), kalendáriom (1705/98), purgatoriom (1706/109), tobákol (1706/185).

Az ü/ü szintén csak szórványosan szerepel nyíltabb, ö/ö vokálissal: bödös (1707/193), csötörtökön (1705/70), Küköllö (1699/25), körölötte (1708/213), nélköl (1708/236), föszerszám 'füszerszám' (1708/250), rósaszínő (1708/224).

Nyílt a-zás csupán a meghalmaztam 'meghalmoztam' (1710/374), valamint a Küköllö várat 'Küküllővárott' (1699/25) szóban található.

2.1.2. Labiális-illabiális megfelelések. Bár az északkeleti nyelvjárási régióban az ö-zés nem tartozik a gyakori jelenségek közé, Barkóczy Krisztinának a 1718. század fordulójáról származó leveleiben is tapasztaljuk ezt a jelenséget, amely csupán néhány ige- vagy névszótövet érint. Leggyakrabban levelek keltezésével kapcsolatban: költ (levél) (1710/361), de elöfordulhat az elkel, telik ige tövében is: költ el (1705/65), tölt 'telt', (1710/343), valamint a becsület fönév hangsúlyos szótagjában: böcsületet (1705/61), továbbá szórványosan néhány más szóban is: Fölsége (1698/20), körületit (1708/226), olykor pedig hangsúlytalan szótagban: csökönik 'csökken' (1710/322), örög (1708/262).

Szótőben az $s z / v$ tövü igékben - grammatikai kötöttséggel - a befejezett és az elbeszélö múltban használatos: öttem (1710/355), löt (1710/335), elvötték (1705/83), vöttem (1708/208), rávöttük (1709/282), töt (1706/186), lövék 'levék' (1708/213), ,hova lövének” (1705/92), tövék (1710/316); e hangalakoknak a vizsgált területen való meglétére több nyelvjárástörténeti tanulmány is utal (CSÜRY 1929: 13; PÁlYI 1897: 496; PAPP 1959: 59; RÉVAY 2010: 21-22). PAPP LÁSZLÓ szerint a 16. században ez a jelenség hozzátartozott a deáki nyelvváltozathoz, de ,a tött, lött, vött alakok egyáltalán nem a tulajdonképpeni ö-zés példái a XVI. század végi írott nyelvben, nem az $\ddot{o}$-ző írott nyelv hatására terjedtek el, hanem az $\ddot{o}$-zés más eseteitől függetlenül keletkezett formák, amelyeket azonban ennek a nem $\ddot{o}$-ző területnek az írott nyelve hathatósan felkarolt, ezzel is csökkentve az e-féle hangok túltengéséből adódó egyhangúságot” (1961: 212-213). Ez az egy évszázaddal ko- 
rábbi, kötött helyzetekben való $\ddot{o}$-zés valószínűleg e terület 17. századi normájának is része lehetett, sőt Kárpátalján ma szükebb területen ugyan (Visk és Kerekhegy nyelvjárásában), de még mindig él (vö. LIZANYEC-HORVÁTH 1982: 7).

Az $\ddot{o}$ szerepelhet toldalékok, így a tárgyrag: bennünköt (1705/72), emberünköt (1710/362), időmöt (1709/297), ökrököt (1710/387), segedelmünköt (1703/31) és a birtokos személyjel elött: körülötöm (1710/302), valamint a modalis-essivus ragban is labiális tőbelseji magánhangzó után: bővön (1705/69), örökösön (1705/65), szükön (1706/101); de akad példa a toldalék előtti ö-zésre is: engesztöljük (1709/291).

Az ismer esmer igének és származékainak a TESz. által (2: 238) eredetibbnek tartott felső nyelvállású, palatális illabiális szókezdő magánhangzója helyén, valamint a kicsiny szó tövének hangsúlytalan szótagjában nyíltabb és labiális magánhangzó található: ösmer (1705/64), ösmerkedet (1705/100), ösmerték (1710/302), kicsönybe (1710/387).

Az $i$ hangsúlyos szótagbeli labializálódása csupán egy szóra korlátozódik ezekben a szövegekben, de ezt a szót következetesen így használja Barkóczy Krisztina: üdöre (1698/16), üdőnk (1710/373).

A fenti jelenségek ellentéte, az illabiális ejtés csak szórványosan tapasztalható, részben az $\ddot{u} \sim i$ : igy 'ügy' (1704/39), igyet (1703/30), izent (1698/173), másrészt az $\ddot{o} \sim e$ esetében: esze 'össze' (1710/365), megkennyebedik (1708/265), tepreng $(1711 / 402)$. Az északkeleti régióban az ö-zés rovására felbukkanó ë-zést már a 16. században is az írott nyelvi normán kívül esőnek tartja PAPP LÁszLÓ (1961: 213).

2.1.3. Rövid-hosszú hangmegfelelések. Gyakori az $l$ kiesése mássalhangzó előtti helyzetben: feszabtunk (1711/391), illetve a kieséssel együtt járó magánhangzó-nyúlás, amelyet a levélíró többnyire jelöl a szövegekben; pl. az ol/ öl > ólö: bóthajtás (1708/226), „bóton felyül” (1708/226), Miskócrul (1698/19), de: Miskolcrul (1698/22), Módvát (1710/385), de: Moldovába (1711/394), legócsób (1710/363), ócsollom (1710/313), de: olcsóságot (1711/394), ócsvaiak (1704/34), de: Olcsván (1710/363), ódalra (1709/290), „ottot mész” (1708/207), agyonlövődözni (1705/98), ötözetet (1710/302). E jelenség kapcsán megjegyezzük, hogy az $l$ zárt szótag végéről való ejtésbeli kiesésének és pótlónyújtásának sajátos jelöléseként BENKÖ még a 18. század második felében is normának tekinti a vólt, fóld írásmódot (1961: 379). A 17-18. század fordulójáról való példáinkban azonban az $l$ jelöletlen marad.

A fenti hangváltozás ellentéte, ABAFFY szavával élve (2003: 302) a túlhelyesbített, hiperkorrekt forma, az $o ́ s$ és $\dot{u}>u l$ változás is felbukkan a levelekben: azolta (1698/21), holnap 'hónap' (1708/232), legutólb (1710/329), miolta (1705/73), valamiolta (1705/61), bulcsút (1708/251).

2.1.4. A hiátus megszüntetése. A bivaly szónak a TESz. szerint a 16-18. században bial volt a legelterjedtebb alakja (1: 308), s ez a szóalak megtalálható Barkóczy Krisztina egyik levelében is: bialt (1706/105); más helyeken viszont $j$ hiátustöltő hangot jelöl a szóban: bijalokot (1706/105, 1710/380). A latin eredetü jezsuita szó előfordul hangzóhiánnyal: jesuiták (1705/98); de a TESz. által is említett (2: 274) $v$ hiátustöltő is megtalálható a szóban: jesuviták (1710/357); 
akárcsak magánhangzóra végződő szóban az -an modalis-essivus rag előtt: hasonlóvan (1710/312), illetve a riaszt ige tövében: rivaszon (1710/312). A $h$ az együhé (1710/302) és a Kánahán (1710/385) szóban jelenik meg hiátustöltőként.

2.1.5. Asszociációs változások a magánhangzók körében. A vegyes hangrendủ szavak részben belső keletkezésü szóösszetételek, amelyekben végbemehet a hangrendi illeszkedés, így a sehol szóban és származékaiban az összetétel elötagja se > so hangváltozást mutathat: sohol (1706/109), sohonnét (1710/347). A hol névmási határozószó és a mi névmás mondattani tapadásából létrejött holmi (TESz. 2: 134-135) szóban a vizsgált nyelvterületen a szó elő- és utótagja még nem túl szorosan kapcsolódhatott egymáshoz, ezért nem vegyes hangrendủ szóként toldalékolják, hanem az összetétel utótagjának hangrendjéhez illeszkedve a toldalék palatális magánhangzós: holmimet (1706/109), holmie (1709/282) holmijét (1708/260), holmirül (1709/290). A jövevényszavakban is csak fokozatosan alakul ki a tiszta hangrend, mint ahogy ezt a német eredetü fullajtár szóban tapasztalhatjuk: fellajtár (1708/246), felajtárokot (1710/302), fulajtárom (1710/327).

\subsection{A mássalhangzók jellemzői}

2.2.1. Új mássalhangzó. A középmagyar korban megjelenő $d z s$ csupán az oszmán-török eredetü dzsida(szúrás) (1698/17) szóban fordult elő, de jelölése vagy kiejtése is még ingadozó, mivel a szókezdő mássalhangzó cs is lehet: csidaszúrást (1698/15).

2.2.2. A zs hang jelölése a levelekben. Ez a hang $z s$ betủvel csupán egyszer fordult elő a rozs (1708/230) szóban, bár ugyanennek a szónak $s$-sel írott formája is felbukkan: ros (1705/65). Minden más szóban s-t ír Barkóczy Krisztina: Alamisnás Szent János (1710/337), ellebselvén (1711/390), gusalyainak (1710/366), karmasin (1706/170), mása 'mázsa' (1710/373), musaiak (1710/331), sákmányra (1706/163), sarolom 'nyaggatom' (1710/308), sémbelödö (1710/307), sibonganak (1706/123), sinóros (1705/84), soldosokrul (1705/73), strásáltatom (1708/219), tösérek (1706/128), visgálják (1710/304). Ez az írásmód valószínüleg nem egyezik a kiejtéssel, tehát nem zöngétlenedésről van szó. KOROMPAY KLÁRA szerint a középmagyar korban a $z s$ hangot a misszilis levelekben még mindig $s$-sel jelölik (2003: 580), de a korabeli nyomtatványokban és nyelvtanokban is ez a jelölés található (2003: 584-589).

2.2.3. Palatalizáció. Az $n \sim n y$ váltakozása. Intervokális helyzetben vagy szó végén az $n$ palatalizálódhat: debrecenyi (1703/31) debreceni (1704/35), elöbbenyi (1708/254), idegeny (1703/29), kordoványokrul (1708/241), megpenyészedet $(1705 / 92)$.

Gyakori az $l>l y(j)$ palatalizáció (spirantizáció) is: érmellyékibe (1710/331), felyül (1708/226), kanallyat 'kanalat' (1708/210), kaplyonyi 'kaplonyi' (1706/145), köböly (1708/264), lyányunknak (1705/83), mellyrevaló (1710/302), Maros mellyékén (1705/95), pályinkafözés (1706/128), semlyekását (1710/340), szélkólyika (1706/ 174). Az $n$ és az $l$ palatalizációja tulajdonnevekben is megtalálható; családi birtokuknak, Gelénesnek a nevét még a keltezésekben is ny-nyel használja a levélíró: Gelényes (1711/400), de más hely- és személynevekben is megtalálható ez a változás: Selymecrül (1706/121), Melyitné 'Melitné' (1705/52) (Melith Pál báró, a kurucokhoz elsőként csatlakozó fönemes felesége) (vö. FOGARASSY-KOVÁCs 2011: 430). 
FÜLEP IMRE a szatmári városoknak - köztük Szatmárnak - a környező falvakétól erősen elkülönülő nyelvjárásával kapcsolatban foglalkozik az ly használatával is, amely szerinte felekezeti elkülönülést mutat a városban (1880: 264), ugyanis a kálvinisták ly helyett tiszta $j$-t mondanak, ,a római és görög katolikusok ly-et ejtenek, ritkábban $l$-et”. Nem csoda hát, hogy Barkóczy Krisztina, aki nemcsak buzgó katolikus, hanem férjével együtt a katolikus egyház aktív támogatója, templom- és klastromépítés szervezője, írásában a Szatmár városát jellemző katolikus szokást követi az ly-ezés tekintetében. A fent felsorolt szóalakok többnyire az SzT.-ben is megtalálhatók: felül, felyül (szócikk címszavaként) (SzT. 3: 1115), mellyékére (SzT. 9: 48), de a kaplyoni szóalak sem meglepő, hiszen e honfoglalás kori nemzetség ótörök eredetü neve BURA LÁszLó szerint Kaplony Kaplyon alakban is élt (2011: 69). Teleki Domokos írásában BENKÖ LORÁND még a felvilágosodás első szakaszában is kimutatott ly-ező alakokat: felyülröl, Mellyékéhez, Pulyiszkát (1960: 476), amelyeket abban a korban már a provinciális vonások közé sorolt.

ABAFFY az ly-ezés megőrződését a középmagyar korban a középső palóc nyelvterület mellett egyes erdélyi, illetve moldvai csángó nyelvjárások jellemzőjeként említi (2003: 598). Példáink arra utalnak, hogy az ly-ezés az északkeleti nyelvjárás peremterületein is élhetett szórványosan, de az ABAFFY által a középső és keleti nyelvjárások sajátosságaként számon tartott j-zés Barkóczy Krisztina leveleiben nem tapasztalható. Ugyanakkor előfordul a túlhelyesbített írásmód (ABAFFY 2003: 598), amikor a j-t ly-nal írja: széllyel 'széjjel' (1708/241), széllyeljárás (1710/319), széllyelküldözöm (1710/363).

Megemlítjük még, hogy a $d$ gy-vé palatalizálódhat: Abrugybányára (1706/143), a szóvégi $h$ hang pedig Zilah nevében j-vé: Zilaj (1708/241).

2.2.4. Depalatalizáció (vagy a palatalizáció hiánya). E jelenség az $n y \sim n$ használatában tapasztalható, főleg mássalhangzó előtti helyzetben, de olykor szó elején vagy szó végén is $n$-t olvashatunk: bársont (1706/106), dohánt (1706/142), dolmántul (1705/68), hánt-vetettekel (1710/356), kénszerittessék (1698/17), leánt (1698/20), sáfránt (1708/239), serinkedik (1705/72), sínlik 'sínylödik' (1703/30), takarmánt (1704/35), törvéntelen (1705/68), hitván (1706/169), kicsin (1705/74), nestbéllést (1705/93), nusztot (1704/36). A depalatalizáció képzéshely-eltolódással jár együtt a hagy és a létige alakjaiban: hadta (1698/17), hadni (1705/73), vadnak (1704/38).

2.2.5. Affrikáció. A deverbális és a denominális $-z$ igeképző, valamint a $g y+z$ néhány szóban $d z$-vé affrikálódik: kéredzik (1706/114), kéredzet (1706/132), kéredzeni 'kérezkedni' (1707/201), letördelődzik (1708/255), jedzéskébe (1710/334), feljedzettem (1710/374). Az sz hang c-vé affrikálódhat: atlacot (1706/154), étzaka (1706/152). A $z s>c s$ affrikáció is megtalálható két idegen szóban: incsinér 'inzsinér' (1705/73), bagacsiájábul 'bagázsia' (1706/167). A séza 'cséza' (1704/37) 'könnyü, rugós lovas kocsi, homokfutó' szóban valószínüleg még örződik a németből átvett szó eredeti mássalhangzója (ném. R. chaise, ir. felsőnémet R. schesa < fr. chaise; TESz. 1: 517), és nem ment végbe az affrikáció.

2.2.6. Zöngétlenedés és zöngésülés. Ez a változás leggyakrabban a Bodrog folyó nevében figyelhető meg, akár magánhangzó vagy zöngés mássalhangzó szomszédságában is: Bodrok (1710/358), Bodrokon (1710/368), Bodrokbul 
(1710/355), Bodrok közi (1706/182), Bodrokköz (1710/353), de szórványosan néhány más szóban is megtalálható: serekkel 'sereggel' (1710/387), „bezzek én is" (1708/213), kavallérságát (1706/107). Zöngétlenedés és képzéshely-eltolódás történik a $z>s$ változásban a zacskó szóban, bár a szó hangalakja ingadozó: zacskó sacskó (1708/224). A jelenség ellentéte, a zöngésülés csupán a Judka szóban fordul elő (1710/345), amelyben a név eredeti Judit alakjában szereplö $d$ mássalhangzó hatása is szerepet játszhat.

2.2.7. Szórványos hasonulások. Hátraható hasonulás történik az $r l: l l$ és $r: l \sim$ l: l esetében: Ollai 'Orlay' (1704/37) (Orlay Miklósnak, Thököly emigráns katonasága vezetőjének; vö. FOGARASSY-KOVÁCS 2011: 431) neve csak hasonult formában szerepel), Sallós Boldog Aszony (1708/213), sallójokkal (1708/232), mélföldet 'mérföldet' (1710/387). Elöre ható hasonulás is történhet az $r: l y>r: r$ találkozásakor: esztergáros (1708/239). A latin eredetủ mazsola szóban (lat. malosa $>\mathrm{m}$. mazsola) még nem történt meg a hangátvetés: „malosa szőlő” (1708/250).

2.2.8. Szórványos változások. Spirantizáció a $c s>s$ változásban következett be: bestelenséget (1709/293), zárhangúsodás pedig a jön ige elgyőne (1709/277) alakjában. Mássalhangzó-kiesés a cafragot (1705/81) és a férhez (1711/406) szóban történt. Az idegen nyelvekből átvett, mássalhangzó-torlódásos szavak egy részének még nem rögzült a végleges hangalakja. A szó eleji torlódásnak előtéthanggal való feloldása tapasztalható a latin scola szó magyar megfelelöjében: oskola (1708/242), a latin (ho)spitale szóból pedig átmenetileg ispitály (1709/296) lesz. A torlódó mássalhangzók közé illesztett bontóhang segíti a kiejtést a zlot szóban, amely az SzT. szerint régi kelet-európai arany pénznem neve (14: 739-40), s Barkóczy Krisztinánál zoltot alakban olvashatjuk (1708/218).

2.2.9. Mássalhangzónyúlás. Az ómagyar kori geminálódás folytatására ABAFFY is utal a középmagyar kor hangállapotának leírásában (2003: 600). Adataink arról tanúskodnak, hogy ez a változás az északkeleti nyelvjárási régióban is jelentkezik. Leggyakrabban az $l, l y$ (föleg névmásokban) és az $s$ hang esetében, de érinthet más mássalhangzókat is, így az $m$-t, $n y$-t, a $b$-t és a $c$-t: beszélli (1698/17), felölle (1698/14), ötöllök (1705/72), vélle (1705/67), gellényesi (1710/363), kaszállás (1705/73), szóllót (1705/78), amellyikbül (1705/62), illyen (1705/62), mellyben (1705/62), gállyáknak (1706/118), hálóhellyen (1708/269), személlyét (1705/98), újhellyi (1706/112), adóssokon (1698/19), inassirul (1710/363), jósságos (1705/67), lapossán (1705/64), ménessét (1710/364), nyerességem (1710/378), terminussa (1706/103), egyetmásommot (1706/142), gyékénnyeket (1706/174), labbancok (1704/38), rabbok (1710/339), éccaka (1708/216). A mássalhangzó-nyúlás olyankor is tapasztalható, amikor az jelentésváltozáshoz vezet: vettek 'vetek' (1708/261).

2.2.10. Mássalhangzó-rövidülés. A fenti változás ellentéte, a mássalhangzórövidülés bekövetkezhet szó belsejében vagy szó végén. Szó belsejében: ahoz (1698/20), akor (1698/15), ara (1710/364), edig (1705/61), egéségem (1705/69), erösége (1708/235), lasan (1698/19), mere (1705/61), regel (1705/71), roszat (1710/364), semiképen (1698/22), had 'hadd' (1710/364). A fenti példák közül a semiképen szóalakot emeljük ki, amelyről BENKŐ azt mondja, hogy még a 18. század végén is ,a norma, illetőleg a provincializmus szempontjából megállapít- 
hatatlan kettősség mutatkozik" (1960: 379) az írásában. A -val, -vel határozórag és a felszólító mód jele mellett nem mindig nyúlik meg a mássalhangzó: ezel (1705/67), szekerekel (1710/372), kerestesen (1710/382), mászanak (1710/385), szakasza fel (1708/256). Szó végén általában rövid a befejezett múlt jele: elhozot (1710/364), jöt (1698/19), let (1705/83); a locativuszi -t: együt (1699/24), holot (1705/71), it (1706/101); az -n határozórag: fen (1705/73); a középfok jele: töb (1705/61), de a szó végi hosszú mássalhangzó is rövidülhet: kel 'kell' (1705/70, mak (1710/364).

3. Összegzés. Barkóczy Krisztinának köszönhetően részletes képet kapunk a kései középmagyar kor északkeleti régiója peremterületeinek, főleg az ugocsai, beregi és szatmári területek 17-18. századi nyelvjárásának hangtani jellemzőiről. Mivel a terjedelmes anyagon elvégzett vizsgálat egyetlen személyhez kötödik, nincs lehetőségünk a korabeli norma és az északkeleti dialektus viszonyának bemutatására. A terület nyelvi normájának 16. századi jelenségeit vizsgáló PAPP LÁSZLÓ és a 18. század végének északkeleti szerzőivel is foglalkozó BENKÖ LORÁND megállapításai jelenthetnek támpontokat a 17-18. század fordulójának kutatásában. A mai magyar nyelvben már nem elfogadott, de általuk a jelzett korszakban normatívnak ítélt hangtani jelenségekre (vött, vólt, képen) a megfelelö helyeken utaltunk is. A levelekben olvasható egyes hangtani jelenségek - peremterületről lévén szó - rokonságot mutatnak a keleti nyelvjárási régió jellemzőivel.

Az északkeleti régió nyelvjárási sajátosságai közül a zártabb magánhangzók kedvelését (i $i$-zés, $o$-zás), az $n$ palatalizációját, bizonyos szavakban a szóbelseji mássalhangzók (elsősorban az $l$, $l y$ és $s$ ) geminálódását, valamint a szóbelseji mássalhangzók rövidülését emeljük ki, amelyek azonban nem tengenek túl a vizsgált levelekben. Ezek és az olykor ingadozó írásmód alapján azt mondhatjuk, hogy Barkóczy Krisztina írott nyelvhasználata átmenetet képez a dialektus és az irodalmi nyelvi norma között.

Kulcsszók: nyelvjárástörténet, nyelvtörténet, középmagyar kor, északkeleti nyelvjárási régió, hangtani jellemzők.

\section{Hivatkozott irodalom}

E. ABAFFY ERZSÉBET 2003. Hangtörténet. [Középmagyar kor.] In: KISS-PUSZTAI szerk. 2003: 596-609.

BENKŐ LORÁND 1960. A magyar irodalmi irásbeliség a felvilágosodás korának első szakaszában. Akadémiai Kiadó, Budapest.

BURA LÁszLó 2011. Szatmár megye történeti-etimológiai helységnévtára. Státus Kiadó, Csíkszereda.

CsŰRY BÁLINT 1929. A tiszaháti és ugocsai nyelvjárás nevezetesebb sajátságai. Magyar Nyelv 25: 11-16.

N. FODOR JÁNOS 2008. Északkelet-Magyarország személyneveinek komplex elemzése. 1401-1526. PhD-értekezés. 1. kötet. ELTE BTK, Budapest. http://nfodorj.web.elte.[-] hu/index_elemei/page0003.htm (2017.03. 19.) 
FOGARASSY ZOLTÁN - KOVÁCS ÁGNES szerk. 2011. Barkóczy Krisztina levelei férjéhez, Károlyi Sándorhoz. Első kötet (1698-1711). A Debreceni Egyetem Történelmi Intézete, Debrecen.

FÜLEP IMRE 1880. A Szatmár városi nyelvjárásról. Magyar Nyelvőr 9: 263-265.

JUHÁSZ DEZSÖ 2001. A nyelvjárási régiók. In: KISS JENÖ szerk., Magyar dialektológia Osiris Kiadó, Budapest. 262-316.

KOROMPAY KLÁRA 2003: Helyesírás-történet. [Középmagyar kor.] In: In: KISS-PUSZTAI szerk. 2003: 579-595.

LiZANYEC P. N. - HoRVÁTH K. I. 1981. A Kárpátontúli magyar nyelvjárások főbb sajátosságairól. Magyar Nyelvjárások 24: 3-18.

KISS JENÖ - PUSZTAI FERENC szerk. 2003. Magyar nyelvtörténet. Osiris Kiadó, Budapest. PÁLYI GYUlA 1897. Mátészalka és vidéke nyelvjárása. Magyar Nyelvőr 26: 494-499.

PAPP LÁSZLÓ 1959. XVI. század végi nyelvjárásaink tanulmányozása. Nyelvtudományi Értekezések 19. Akadémiai Kiadó, Budapest.

PAPP LÁSZLÓ 1961. Nyelvjárás és nyelvi norma XVI. századi deákjaink gyakorlatában. Nyelvtudományi Értekezések 25. Akadémiai Kiadó, Budapest.

RÉVAY VALÉRIA 2010. A nyelvhasználat szintjei a XVII-XIX. században Északkelet-Magyarországon. Iskolakultúra-könyvek 39. Iskolakultúra, Veszprém.

SzT. = Erdélyi magyar szótörténeti tár 1-14. Főszerk. SzABÓ T. ATTILA etc. Kriterion Könyvkiadó etc., Bukarest etc., 1975-2014.

TESz.= A magyar nyelv történeti-etimológiai szótára 1-3. Főszerk. BENKÖ LORÁND. Akadémiai Kiadó, Budapest, 1967-1976.

\section{On the phonology of the North-Eastern dialect area in the period of Late Middle Hungarian, based on Krisztina Barkóczy's letters}

This paper explores phonological phenomena of the North-Eastern dialect area in the period of Middle Hungarian, on the basis of Krisztina Barkóczy's letters to her husband, General Sándor Károlyi between 1698 and 1711. Krisztina Barkóczy (1670-1724) lived in Ugocsa and Bereg Counties, and later in the Károlyi estates in Szatmár County. The texts follow the literary norms of the period but they also reflect contemporary spoken Hungarian. From them, we get a taste of the major phonological properties of the dialect of the region: its preference for close vowels, the extended distribution of $/ \mathrm{i}: /$ and $/ \mathrm{o} /$, the use of $/ \varnothing /$ in inflected forms of $/ \mathrm{s} / \sim / \mathrm{v} /$-stem verbs, the preference for palatal sonorants $(/ \mathrm{n} />/ \mathrm{n} /, / 1 />/ K /)$, the gemination of $/ 1 /, / K /, / \mathrm{J} /$, and the frequent occurrence of consonant shortening.

Keywords: historical dialectology, historical linguistics, Middle Hungarian period, NorthEastern dialect region, phonological properties.

RÉVAY VALÉRIA

Pannon Egyetem 